\title{
Commercial Security's' Effect on Security of Kenyans in Private Venues
}

\author{
Gerald Peter Mutonyi ${ }^{a^{*}}$, Ann Sirera ${ }^{a}$ \\ ${ }^{a}$ Kenyatta University, Nairobi, Kenya
}

\begin{abstract}
The strategic interplay between the Commercial security industry and security is complex. The realists view the provision of security as a fundamental obligation of the state. But to the liberalists, the pursuance of security can be achieved with the involvement of other actors offering the same. The question of whether the growing recognition of commercial security industry has marked an important shift in the norm of the state monopoly on violence in Africa needs answers. Despite this development, few studies have evaluated the effect of commercial security on security in Private Venues. Using Situational crime prevention theory, this study sort to demonstrate the effect of commercial security on security of Kenyans in Private Venues. The study adopted a cross sectional survey design, and was carried out in Nairobi with the target population of the adult residents in Nairobi. Customers and management of the commercial security industry were purposively sampled, whereas the general public and the security guards were systematically sampled. Questionnaire, interviews and structured observation were used to collect data. Qualitative data was analysed thematically. While quantitative data was analysed using descriptive statistics like percentages, average and mean, and pie charts. There is an accepted positive effect on security of Kenyans in private functions and venues where commercial security present. But efficiency would be achieved if, the commercial security personnel provide indiscriminate security responses where there is a breach. Grey area needing legal backing were identified as: arming of the commercial security personnel, proper uniforms and kitting, and training and skills. It is expected that the findings of this study will be of great significance to the commercial security industry stakeholders in their quest to provide security to their customers. The findings will also be used to inform policy and practice that can beneficial to national security in Kenya. It is also hoped to stimulate the academic community and the government of Kenya towards more research in the field, and for the formulation of policies that will improve the general security of the citizens.
\end{abstract}

\section{Keywords:}

Commercial Security

Commercial Security Firms;

Security;

Private Functions and Venues.
Article History:

$\begin{array}{llcc}\text { Received: } & 01 & \text { June } & 2018 \\ \text { Accepted: } & 14 & \text { August } & 2018\end{array}$

\section{1- Introduction}

Safety and security remain amongst the most noticeable basic needs of people, from the ancient times as threats and risks cause emotional, economic or physical harm. Threats and risks deterrence is a worthy cause and whatever that can be so considered by implication brings a noble deal of service [1]. The need for security is therefore combined with resources to discourage and minimize the potential enormity of real or imagined danger [2].

The implementation of these objectives is what is referred to as national security. The notion of a state was influenced by the views of Max Weber, and the provision of security was viewed as the most fundamental obligation and task of the state. The 'Weberian State' was perceived to enjoy the monopoly of the legitimate use of physical violence [3]. According to Western tradition, the state is responsible for the provision of internal security and defence from external threats in the territory that it has legitimacy.

Notably however, that state institutions, are limited in ensuring equity in the distribution of security to all members of society [4]. The state may concentrate tailored provision of security to its important installations and some citizens, whereas the general population and their property are placed in a one fit all suit despite the varied security needs. The different needs of security by different people within the state places many demands that are beyond the capability of the state, making it difficult for equal distribution of security service. Therefore a range of actors are now explicitly

\footnotetext{
*CONTACT: Mutonyig@gmail.com

DOI: http://dx.doi.org/10.28991/esj-2018-01142

(C) This is an open access article under the CC-BY license (https://creativecommons.org/licenses/by/4.0/).
} 
looked upon to supplement the supply of security services [5]. Arguably the most important of these new actors is the commercial security industry (CSI), which has grown expansively in both developed and developing countries.

\section{2- Security}

Security can be defined as a pursuit of freedom from threats [6]. It can also be defined as deliberate activities, which identifies dangers and the objects that need to be secured and, engages these dangers over a prolonged period [7]. From this definitions, it is possible to argue that many activities from different players in security combine to provide security of people. Towards this end security is no longer only the concern of national governments. However, it is important to acknowledge the central role of the state in security issues, as traditionally, argued by the neorealist the focus was on military activities, the control of military hardware, and actions against armed groups and networks [8].

The growth of societies and the complexity of urban life increased demand of security leading to alternative modes of security. Therefore, the state security alone hardly sufficed to provide security in a manner consistent with developmental objectives. Increased pressure on the law enforcement community resulted in the privatization of some of National police functions, with the Commercial Security firms (CSF) filling the gaps left by the overstretched police and playing a growing role in the safety of the community [9].

\section{3- Commercial Security}

A century ago, night watchmen and security guards were giving protection to citizens and ensuring their safety in the cities of central Europe. Additionally, in house security guards were commonplace in industrial companies during that period [10]. For example in Britain, they were operated by a magistrate, Henry Fielding, but they were funded by the businesses and in that sense they were also 'commercialized security' conducting residential patrols [11]. Today the tendency to rely on commercial organizations to provide security has increased and growing exponentially during the last two decades [12]. There is hence a range of non-state police groups that are engaged in different ways in 'policing' [13].

A number of studies have correlated the growth of commercialized security markets with deficits in the capacity of states to effectively deliver security-related services $[14,15]$. Commercialized security, in this understanding, becomes "symptomatic of state weakness". If a state can no longer meet its citizen's demands for certain security services, those who can afford it turn to commercial providers [16]. Second, the phenomenon of increase of transnational flows of capital, goods, services, and people, which has been favored by the development of the economic liberalization, has diminished the importance of the state's regulative powers [17].

In that regard, commercialized security are now a noticeable sector around the world and in Africa. A review of 70 countries, estimated that the formal commercial security as having between 19.5 and 25.5 million personnel worldwide [18]. Indeed, the undertakings carried out by commercial security firms (CSFs) are wide with security products and services: CCTV, burglar alarm and access control, and manned guarding. Worldwide there is no security role carried out by the police that is not embarked on by the commercialized security in some arrangement [19].

A classical definition of commercial security is, "the safeguarding of assets, personnel and even profitability of the organization against theft, fire, fraud, criminal damage and terrorist acts" [20]. Commercial security is also policing and security, like many other services, that are commodified and are available for consumption by a client base willing to pay for the service [21]. It can also be defined as the preservation of security of people, information, and property by using both manpower, alarm and surveillance technologies [22].

In Kenya, among the services that the CSFs offer are, site or mobile patrol functions, loss prevention functions, special venues security, investigation services and in-house security [23]. The Kenyan Interior Cabinet Secretary Dr Fred Matiang'i in May, 2018 announced plans, to arm the commercial security personnel as part of a new strategy to curb insecurity and complement state security agencies [24]. But the government has not been able to explain whether that rationale is justified with the success or failure of commercial security industry. There is also a progressively growth in CSFs, therefore becoming one of the areas with the fastest growth in Kenya's economy [23]. But again, there has been a sharp rise in criminal activities and insecurity in the Nairobi County, which is the capital of Kenya [23]. It is against this background that it important to understand how commercial security in Kenya, has affected security of Kenyans in private functions and venues.

\section{4- Literature Review}

Private and public customers are making engagements for commercial security services. Even both government and non-governmental organizations employ the services of CSFs to protect their assets [25]. Arising from these, the reality of commercial security arrangements or delivery of commercial security has developed to a worldwide exercise. Therefore, groups of people are creating their own functions and venues for policing from commercial arrangements, to guarantee the security of lives and properties in their area. This way, governments are by proxy managing to meet their 
duties of providing security.

A study by Cook and MacDonald, indicated a positive economic impact on business groups in such circumstance along with a drop in incidents of criminal or unsafe behavior [26]. Nevertheless, reports by Bennett indicated that, in some instances, commercial security arrangements were used specifically to target homeless persons, ethnic minorities and mentally ill persons in order to keep them out of some public areas [27]. These two studies were carried outside with the former showing positive economic impact on business groups and the latter stating that commercial security were used for segregation purposes but the current study will seek to find out the effect of commercial security on security of Kenyans in private venues.

In addition LaLonde, recorded that in some areas, commercial security arrangements are not merely delivered to guard physical properties or locations, and the engagements are comprise securing of individuals such as dignitaries and celebrities [5]. LaLonde further pointed out that commercial security arrangements in some states are often to protect and secure the movement of valuables generally known as "cash in transit", for which some governments authorize the armament of guards as part of the duties designed to secure such operations [5]. However the current study will explore the commercial security's effect on security of Kenyans in private venues.

Personal security clearances are an example of the spread of security measures into the private functions and venues. Industrial work in sensitive areas or on classified projects regularly require a large but honest personnel. To meet these requirement, organizations embrace personnel security clearance processes for such private functions [28]. In the UK, the threat to security has been intensified further by the increase in the threats that groups such as animal rights extremists nowadays pose to establishments and workers to the targeted industries, activities or functions [29]. Kovacich and McGee has indicated the requirements by the various organizations to use commercial security for visitor clearances, whereas this study will be undertaken to indicate the effect of commercial security on private venues of Kenyans.

Traditionally, semi-public places such as shopping centers and industrial premises had been regarded as natural spheres of influence for manned guarding but guards are now present in the wider public domains of towns and cities [30]. Visitor control, internal and external theft, and fire are major security worries for private hospitals and other healthcare facilities, hence they use commercial security to ensure safety and security in the hallways and control access [31]. While Steden and Hess have shown the expansion of commercial security public domain, the current study will show the effect of commercial security on private domains.

Risks to the students and staff at educational establishments comprise, violence, vandalism, and theft. To mitigate against these concerns, lighting, and commercial security guards are used. For example, the Mackinac Center reported that districts in New York City hired security guards after going through problems with school violence [32]. Because of their open environments, colleges and universities use both proprietary and contractual security personnel to secure their facilities [31]. In the USA, commercial security guards are commonly hired by air carriers to conduct passenger and baggage checks, however, federal law enforcement officers provide overall airport security [31]. The two studies of Mackinac Center and Hess have reported the commercial security have been used to mitigate against risks in educational establishments and airports. This research aims at finding out the effect of mitigating against risk on security of Kenyans in private venues.

In many countries, the great demand for uniformed guard's manifestation on the roads in residential areas, together with the development of gated communities in some nations, has made the provision of venues security to thrive [32]. These gated groups that are residential areas are divided off from their environs by border fences in North and Latin America and in many African States [30]. Commercial security in such a gated groups, undertake access control and watch functions in those venues. But this planning sometimes prove to be a contentious one for the reason that the discordant nature and the inequalities exposed in terms of security amongst those able to afford to live in such zones and those who cannot [32]. Similarly, some public housing authorities hire security guards for access control and CCTV surveillance services in functions and venues [33].

With over 3,000 staff, the commercial security firms provide a wide range of services even in private aviation sites, comprising, access control, issuance of restricted passes and accreditation, routine patrols boarding-gate security controls, crew, cargo and mail, screening of passengers, passenger profiling and permit controls [5]. While these studies have shown the duties and responsibilities of commercial security in the private domain, the current study will be showing the effect of those duties and responsibilities on the security of Kenyans in private venues.

In the Democratic Republic of Congo (DRC) crime statistics are not released and as a result, activities of crime cannot be studied based on official crime statistics like in other countries [34]. Commercial security in DRC mainly offer their services in urban areas [34]. This might be attributed to high crime levels in urban areas in divergence with low crime rates in rural areas as it is the situation in many African countries. The main role of commercial security firms in DRC is the prevention of crime through patrolling, monitoring of alarm systems and armed response, responding to accidents scenes, and rendering first aid where it is needed [34]. However, the current study intends to examine how the use of the prevention of crime through patrolling, monitoring of alarm systems and armed response, responding to 
accidents scenes, and rendering first aid where it is needed, affects the security of Kenyans in private venues.

In Kenya today, high crime rates combined with the inability of the police to provide adequate protection, are the main factors driving the expansion of commercial security [35]. But the National Police Service 2013 - 2018 Strategic Plan is clear in terms of involving partners in combating insecurity in Kenya, but it is not precise on the roles of the partners [36]. The Private Security Regulation Act No. 13 of 2016, Part VI also emphasizes on the cooperation of the commercial security industry with the National Security Organs [37].

The CSFs in Kenya, have responded to insecurity by providing security goods and services, with the aim of assisting citizens to develop their own security [38]. These goods and services include, intruder alarm and response, perimeter protection and access control, guard dogs, cash and valuables in-transit, as well as fire and rescue services. This notwithstanding, there still are cases of increased reports of robberies, car thefts and burglaries and other crimes [38].

There are a few examples of well-documented studies addressing the work of commercial security functions and venues in Kenya. Mbuvi focused on the influences of CSI role on security [39]. Kiama and Bor studied the CSFs and their crime control role [40]. Kaguru and Ombui focused on the factors affecting the CSF's role performances in Kenya [41]. But they did not focused on commercial security's effect on private functions and venues in Kenya which this current study will be exploring.

\section{5- Situational Crime Prevention Theory}

Situational crime prevention (SCP) is a crime theory proposes the reduction of crime by making it impossible for it to be committed no matter what the offender's motivation, by deterring the offender, or by reducing cues that increase a person's motivation to commit a crime.

The originating concept of SCP is "opportunity reduction" [42]. It calls for removing opportunities to prevent crime. The SCP framework includes both "hard" and "soft" interventions techniques to reduce crime [43]. Hard interventions either deter offenders from committing an offense, or make it impossible for the offender to commit the crime regardless of his/her intent or level of motivation. Some SCP hard techniques include, the use of CCTV cameras, the public deployment of security personnel, and environmental design creativities to increase surveillance, as they warn persons that if they offend, they will be immediately arrested [44].

Soft interventions reduce situational prompts/cues that increase a person's motivation to commit a crime during specific types of events [45]. Soft situational crime prevention approaches seek to remove environmental cues or prompts that create, or increase, an individual's motivation to commit crime. For example, publicly displayed weapons by police or security guards, could cause some individuals to become violent. Soft SCP advocates for interventions that eliminate these cues and prompts. For example, a soft situational crime prevention policy would ensure that in certain circumstances a security guard's weapon would not be publicly displayed.

\section{6- Research Methodology}

Cross sectional design was adopted for the study, as different respondents were studied at the same time. It gives a stronger likelihood for participation. It also helped to gather objective information that was used for generalization to a larger population. The design also fits diverse experiences into predetermined response categories.

The research was carried out in Nairobi County, where the capital of Kenya sits and most CPFs have their headquarters. Stratified sampling was used to cluster the target population into homogenous groups as:

Consumers of the commercialized security services:

- Those who buy or manage commercial security services for their organizations. These are mostly security managers and officers, and

- The general public.

And the providers of commercialized security services:

- Those working as operations heads of security.

The research targeted 120 consumers of commercialized security services, divided as 60 as security managers/officers, and 60 from the general public who have experienced commercial security services in functions or venues.

In Kenya, there are 38 listed security firms at the Kenya Security Industry Association, and 76 at the Protective Security Industry Association, totalling to 114 security firms in Kenya [46, 47]. The research targeted both the 38 and 76. The research targeted one respondent per security firm, and confined to those in operations of security.

The researcher delivered the questionnaires at the security firm's offices and picked up within three days. Follow- 
up calls were made to ensure success in filling in the questionnaires. Out of 114 questionnaires which had been administered to the interviewees, 104 of them were returned for analysis.

The researcher also delivered questionnaires to the security manager's/officer's place of work and picked them within three days. Follow-up calls were also made to ensure success in filling in the questionnaires. Out of 60 questionnaires which had been administered to the interviewees, 57 of them were collected for analysis. The researcher randomly sampled 60 respondents from the general public, and all of them were retrieved back.

The data collection instrument was the questionnaire that had both closed-ended and open-ended questions, to allow for further probing for in-depth responses. There was the ethical consideration where the researcher informed all participants of their voluntary participation and confidentiality.

\section{7- Results and Analysis}

\section{7-1- Commercial Security's Effect in Private Functions and Venues}

The respondents as per cluster indicated a positive effect of commercial security in private functions and venues. The results are shown in Figure 1 below:

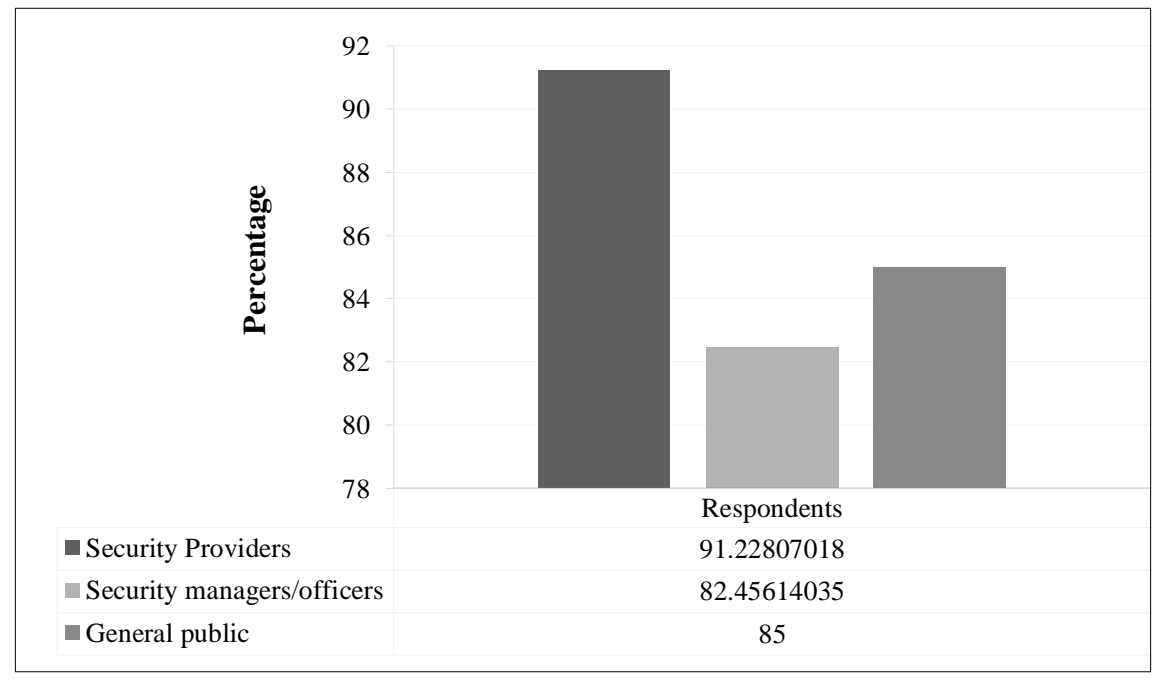

Figure 1. Commercial security effect in private functions and venues.

91 percent of the security providers responded that there is a positive effect on safety and security in private functions and venues where commercial security is deployed. The $9 \%$ that did not find positive effect, alleged that sometimes the guards encounter armed aggressors hence they have to retreat and wait for the police to intervene.

82 percent of the security manager/officers responded that there is positive effect on safety and security where and when the commercial security are deployed. The number that did not exceed $18 \%$ who did not find positive effect, expressed that on more than two occasions, they had experienced insecurity and a breach of safety despite the deployment of the guards.

85 percent of the general public agreed that there is positivism in safety and security in the presence of commercial security. The $15 \%$ that was in disagreement felt that commercial security only responded to the customers who have paid up for the service.

In both scenarios, a statistically significant relation between positive effect on safety and security in private functions and venues, and the deployment of commercial security was established. Therefore, the deployment of commercial security can be a source of safety and security in private functions and venues. This agrees with situational crime prevention "hard" policy that, deterrence of offenders, or make it impossible for them to commit crimes can be achieved by the public deployment of security personnel.

\section{7-2- Security Managers'/Officers' Proposals to Commercial Security Firms}

The respondent's proposals to commercial security firms are shown in Figure 2 below. 


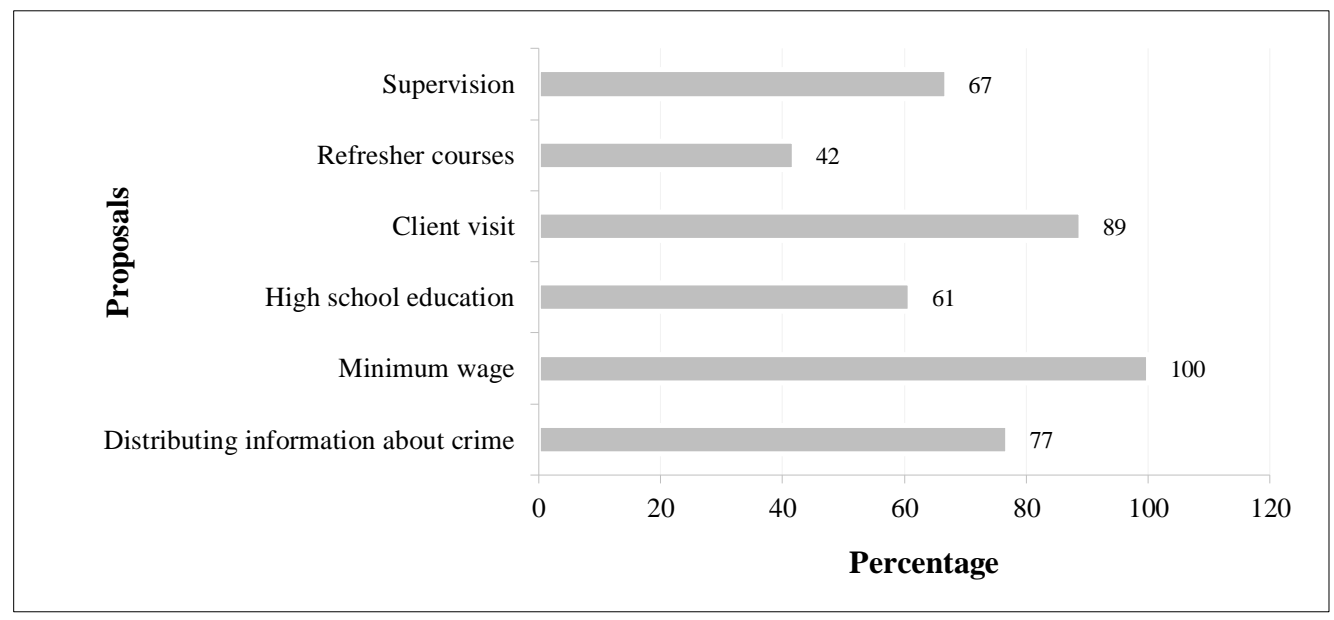

Figure 2. Proposals to commercial security firms.

The results indicate that, all the security managers/officers agreed that if the security guards are paid the minimum wage, there would be a positive improvement on the security of Kenyans. The explanation is that, a genuine remuneration fascinates a person to motivate them to work for it and to work efficiently and effectively.

Client visit was second at $89 \%$. The reason given was that, it helps the management of both the security firms and customers, to customize the site services to address the particular unique requirements.

Distributing information about crime reports was third at $77 \%$. This was justified by the reason that, such information would help the consumers to avoid crime prone habits and to have information on the ever evolving crime trends.

Supervision was at $67 \%$. The respondents were of the view that, security personnel who are constantly watched by their mother organization, tend to be more alert and productive. This is because of biased loyalty to their employer.

More than half of these respondents at $61 \%$ required an education up to high school. They regard security services as beyond crime prevention but more of the first line of image and customer relation of an organization. The high school education, therefore is seen as having equipped guards with proficiency in the English language and some etiquette.

Refresher course was also a concern for the security managers/officers at $42 \%$. It was seen as the basis of the security job and career which has to be nurtured and sharpened at times. Furthermore, due to the revolving nature of crime, the guards should be equipped to deal with the latest trends of deterrence.

From the responses of the security managers/officers, it can be deduced that, they are more concerned with the benefits their organizations will get from improved services of the commercial security. What is their concern are the services that they are paying for. Situational crime prevention theory therefore does not seem to fit in their concerns.

\section{7-3- General Public Proposals to Commercial Security Firms}

The general public also made proposals to the commercial security firms. The proposal are shown in Figure 3 below.

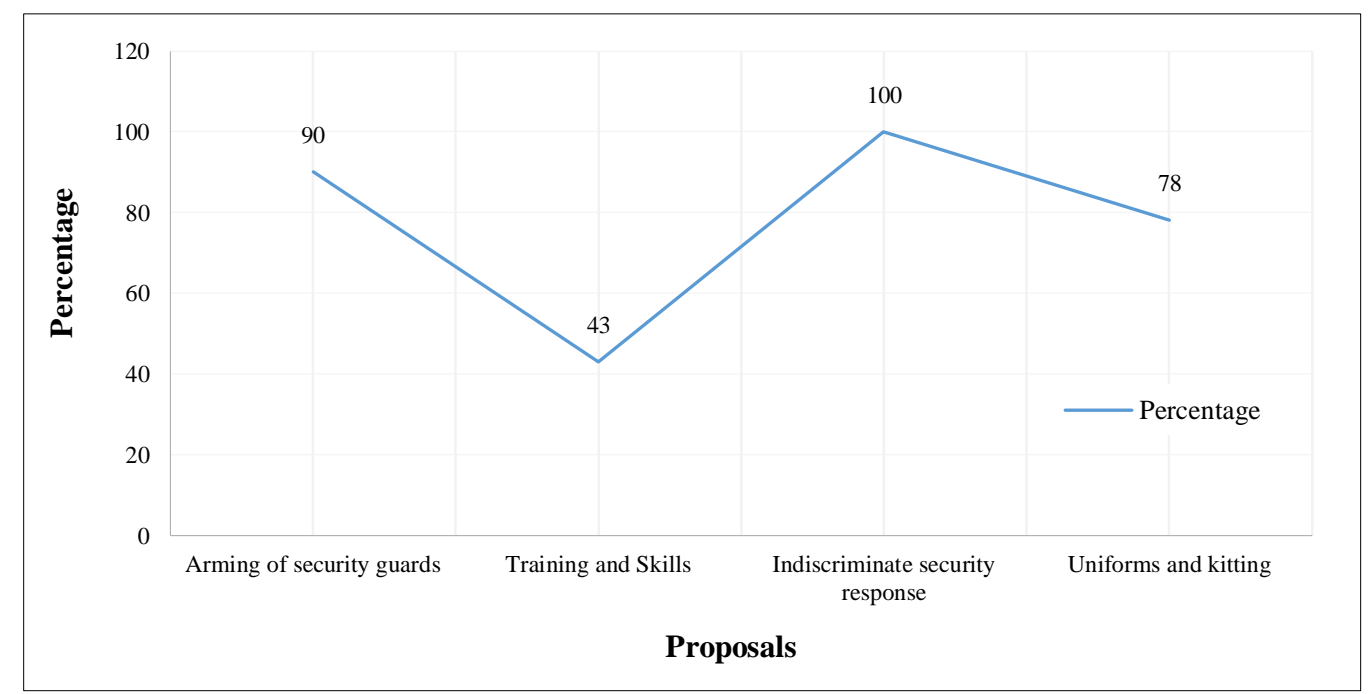

Figure 3. General public proposals. 
From the results above, all the general public respondents proposed to the commercial security providers to indiscriminately provide security responses in cases of security breaches and criminal activities. This is because, they have confidence in the roles of the commercial security personnel, and also due to the more visibility of the commercial security personnel. The responses of security personnel and increase of surveillance, would be a deterrent to offenders. This agrees with the hard situational crime prevention interventions of deterring offenders, and also making it impossible for them to commit crimes regardless of their intent or level of motivation.

90 percent of the general public proposed that, the commercial security should be armed. This is because, most criminals are armed whereas the guards in Kenya are not. Hence it disadvantages the guards. This proposal, did not contradict or support the soft situational crime prevention policy, which advocates that weapons in certain circumstances should not be publicly displayed by security guards. But it concurs with the hard situational crime prevention policy that, the deployment of security personnel, and increase of surveillance would deter potential offenders.

Uniforms and kitting was a proposal that had the general public polling at $78 \%$. A proper and decent uniforms gives an impression of seriousness and authority. This agrees with the soft situational crime prevention approach that seeks removal of environmental cues that would create an individual's motivation to commit crime. Hence no need for public display of weapons but a visible presence of decently uniformed security personnel.

Training and skills was mentioned by a minority at $43 \%$. They felt that due to the revolving nature of crime, the guards should be equipped to deal with the latest trends of crime. This was in agreement with the concern of the security managers/officers who had polled in at $42 \%$.

\section{7-4- Responses from the Providers of the Commercial Security Services}

The commercial security providers' respondents expressed their concerns as shown in Figure 4 below:

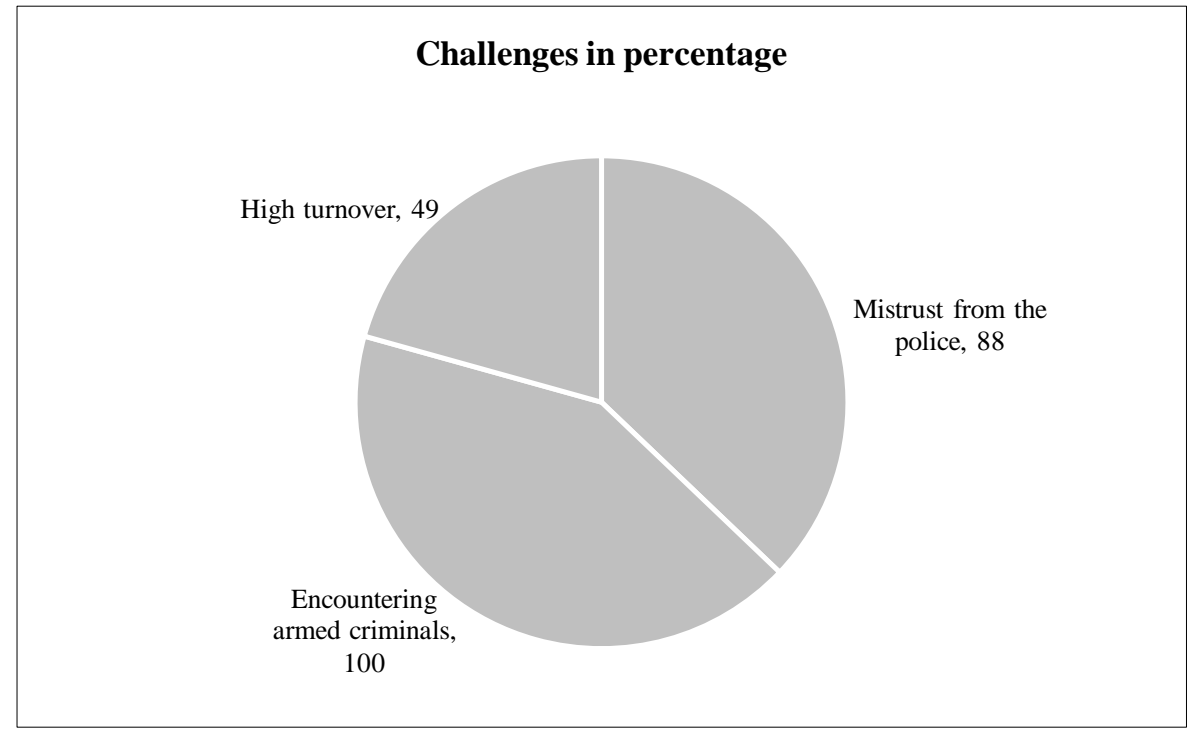

Figure 4. Commercial Security Providers Challenges.

All the commercial security providers raised concern over encountering armed criminals when their personnel not armed. Their personnel are every so often given directives to withdraw and wait for police assistance when faced with such situations. But they remain the first line of defence and therefore at a risk of violence. They expressed concerns that government regulations make it hard to issue security guards with body armour, as this entails a firearms clearance permit. This effects negatively on the effectiveness of providing safety and security to Kenyans.

At $88 \%$, was the mistrust between the police and the commercial security providers. The mistrust is compounded by the perception that the police undermine them by, setting free of suspects, and shoddy investigations to scuttle cases. There is also a perception that some members of the police service are suspicious of the commercial security officers, and will always hold them as suspects even when there is no evidence linking the security officers to an incident.

Lastly, despite the growth of the commercial security sector, there is a notable high turnover of security guards who perceive the jobs as a stepping stone for absorption in other sectors of the economy. This concern was tallied at $49 \%$ from the responses of the commercial security providers. This concern according to them is a costly affair. 


\section{8- Discussion}

Based on the research findings, there is a positive effect on security of Kenyans in private functions and venues where commercial security present. But in order to for these jobs to be carried out efficiently, the commercial security personnel are urged to go beyond their call of duty provide indiscriminate security responses where there is a breach. This is quite controversial as they will be going beyond their jurisdiction. Hence more study can be recommended on how this gray area can receive legal backing.

The arming of the commercial security is currently being proposed by various government agencies but there is no legal framework to regulate such arms in the possession of the CSFs. Therefore, a legal framework and public sensitization, would should be the first step be the implementation.

Proper uniforms and kitting have been a challenge for most midsized CSFs in Kenya, and from the results of the study, if they went a notch higher and improved on it, will it contribute immensely to the safety and security of Kenyans.

Training and skills, is another concern that was raised that would contribute positively to the safety and security of the Kenyans. The management of the commercial security firms should be made to acknowledge the culture of instilling in new knowledge in the guards who are already in the field by having a system of recalling them back yearly for refresher courses.

The managements of the CSFs should also be knowledgeable on the best practices that will increase job retention of their guards. The guards should be made to change their perception and know that their job is a career.

Lastly, Situational crime prevention interventions have consistently been found to reduce crime. But there are criticisms that its interventions simply displace crime and not reduce or eliminate. This displacement is the shifting of crime from one locality to another. Hence another theory of crime prevention should be considered when discussing the effects of safety and security of commercial security in private functions and venues.

\section{9- Conclusion}

In conclusion, with the ever fluid and dynamic terror-related security situations unfolding the world over, commercial security needs to be enhanced. Commercial security is the first line of defence for any citizen at residences or institutions. And as such should be well institutionalized. This calls for a deeper look into this aspect of commercial security in the context of the ever-changing security challenges globally and to which also Kenya is not immune.

\section{0-Acknowledgements}

I appreciate a good friend and mentor Dr. Ann Sirera, of the department of security and correctional science, and the school of security, diplomacy and peace studies at Kenyatta University for standing by me. I also acknowledge the whole fraternity of the school of security, diplomacy and peace studies at Kenyatta University for their effort in modelling security studies.

\section{1- References}

[1] D. Gilling. Crime Prevention: Theory, policy and politics. UCL Press, London, (1997) 8. doi.org/10.1002/cbm.334.

[2] D. G. Steenkamp and P.J. Potgieter. 2004. Private security and crime prevention: A factor analytic approach. Acta Criminologica, 17(2): 71-82 (2004) 2.

[3] L. Philipp and N .Lemay-Hébert. Re-reading Weber, re-conceptualizing state-building: from neo-Weberian to post-Weberian approaches to state, legitimacy and state-building, Cambridge Review of International Affairs, $29: 4$ (2016) 1467-1485. https://doi.org/10.1080/09557571.2016.1230588

[4] M. Boemcken. Commercial Security and Development: Findings from Timor-Leste, Liberia and Peru. Bonn: Bonn International Center of Conversion (2011) 3. http://127.0.0.1:9614/204.

[5] UNODC (United Nations Office on Drugs and Crime). State Regulation concerning Civilian Private Security Services and their Contribution to Crime Prevention and Community Safety. New York: Criminal justice handbook series (2014) 3. http://127.0.0.1:9614/204.

[6] B. Buzan. People, states and fear: An Agenda for security Analysis in the Post-Cold War Era. Brighton 2nd: Weatsheaf (2008).

[7] M. Boemcken. Commercial Security and Development: Findings from Timor-Leste, Liberia and Peru. Bonn: Bonn International Center of Conversion (2011) 5. http://127.0.0.1:9614/204.

[8] H. Karim, G. Donata, and J. Wanjiru. Security and Human Security: An Overview of Concepts and Initiatives - What Implications for West Africa. Paris: Sahel and West Africa Cub, OECD (2004). http://127.0.0.1:9614/204.

[9] UNODC (United Nations Office on Drugs and Crime). State Regulation concerning Civilian Private Security Services and their 
Contribution to Crime Prevention and Community Safety. New York: Criminal justice handbook series (2014) 3. http://127.0.0.1:9614/204.

[10] J. De Waard. The private security industry in international perspective. European Journal on Criminal Policy and Research (1999) 43-174. https://doi.org/10.1023/A:1008701310152.

[11] M. Nalla and G.A. Newman. A primer in private security. New York: Harrow and Weston (1990) 18.

[12] P. Singer. Corporate Warriors: The Rise of the Privatized Military Industry and Its Ramifications for International Security, 26, No. 3, International Security (2001) 189. https://doi.org/10.1162/016228801753399763.

[13] M. Gill, K. Owen and C. Lawson. Private Security, the Corporate Sector and the Police: Opportunities and Barriers to Partnership Working. Leicester: Perpetuity Research and Consultancy International (2010).

[14] C. Holmqvist. Private Security Companies - The Case of Regulation. Stockholm International Peace Research Institute, Paper N0. 9 SIPRI policy (2005) 15. http://127.0.0.1:9614/204.

[15] S. Simelane. Security for All? Politics, Economy the Growth of Private Security in Swaziland. Review of African Political Economy, Vol. 35, N .118 (2008) 599-612. https://doi.org/10.1080/03056240802569276.

[16] T. Mandrup. Privatisation of Security: The concept, its history and its contemporary application. Royal Danish Defence College (2012) 179. http://127.0.0.1:9614/204.

[17] M. Suter. PPPs in Security Policy: Opportunities and limitations. Center for Security Studies, No. 111 (2012) 1. http://127.0.0.1:9614/204.

[18] Small Arms Survey. States of Security. Geneva: Cambridge University Press (2011) 103.

[19] M. Button. Doing Security: Critical Reflections and an Agenda for Change. Basingstoke: Palgrave (2008) 5.

[20] J. Wilson, and T. Slater. Practical Security in Commerce and Industry. London: Gower Publishing (1990) 11.

[21] I. Loader. Consumer Culture and the Commodification of Policing and Security. Sociology, 33(2) (1999) 373-392. https://doi.org/10.1017/s003803859900022x.

[22] D.J. Waard. The Private Security Industry in International Perspective. European Journal on Criminal Policy and Research, 7 (1999) 143-174.

[23] A. Rita and C. W. Michael. Globalization of Private Security Country Report: Kenya, Report prepared for The Department of International Politics, University of Wales (2005). http://127.0.0.1:9614/204.

[24] S. Cherono. Guards to own guns in new security plan. Friday May 11 (2018) 3.

[25] Olaniyan. Unorthodox peacekeepers and responses in Africa. ISS Monograph, No. 183 (2011) 5-12. http://127.0.0.1:9614/204.

[26] J. Phillip and M. John. Public Safety through Private Action: An Economic Assessment of BIDS. The Economic Journal, vol.121, No. 552 (2011) 445-462. http://127.0.0.1:9614/204.

[27] D. Bennet. Security before Justice: A Study of the Impacts of Private Security on Homeless and Under-housed Vancouver Residents. Pivot Legal Society (2008) 14. http://127.0.0.1:9614/204.

[28] G. Kovacich, and E. Halibozek. The Managers Handbook for Corporate Security. Oxford: Butterworth Heinemann (2003).

[29] A. McGee. Corporate Security's Professional Project: An Examination of the Modern Condition of Corporate Security Management, and the Potential for Further Professionalization of the Occupation. Bedfordshire: Cranfield University (2006). http://127.0.0.1:9614/204.

[30] V. R. Steden and R. Sarre. The growth of private security: Trends in the European Union. Security Journal, 20:4 (2007) 222235. http://127.0.0.1:9614/204.

[31] K. Hess. Introduction to private security (5th ed.). Belmont, CA: Wadsworth (2009).

[32] Mackinac Center for Public Policy. Private Protection: A Growing Industry Could Enhance School Safety. Michigan Privatization Report (1998). https://www.mackinac.org/802.

[33] L. Johnston and C. Shearing. Governing Security: Explorations in Policing and Justice. London: Routledge (2003).

[34] K. Strom, M. Berzofsky, B. Shook-Sa, K. Barrick, C. Daye, N. Horstmann and S. Kinsey. The private security industry: A review of the definitions, available data sources, and paths moving forward. Washington D.C, US Department of Justice (2010). http://127.0.0.1:9614/204.

[35] D. M. Goede. Private and Public security in post-war Democratic Republic of Congo. The private security sector in Africa: Country Series. Monograph Series, No.146 (2008) 35 - 68. http://127.0.0.1:9614/204. 
[36] R. Abrahamsen and M. Williams. Globalization of Private Security Country Report: Kenya. Aberystwyth: University of Wales (2005). http://127.0.0.1:9614/204.

[37] National Police Service. 2013 -2018 Strategic Plan. Nairobi: Government printer (2013).

[38] Private Security Regulation Act 13 of 2016 (2016).

[39] Kiama and Bor. Private Security services and crime control in Karen location, Nairobi County, Kenya. IOSR Journal Of Humanities And Social Science (IOSR-JHSS) Volume 20, Issue 10, Ver. IV (October, 2015). PP 84-90. http://127.0.0.1:9614/204.

[40] C. Mbuvi. The Development and Growth of the Kenyan Private Security Sector: Its role and impact on safety and security. Pretoria: University of South Africa (2015). http://127.0.0.1:9614/204.

[41] K. Kaguru and K. Ombui. Factors Affecting Performance of Private Security Firms in Nairobi County: A Case Study of G4S Security Services (K) Ltd. International Journal of Science and Research, 3(2) (2014). 281-286. http://127.0.0.1:9614/204.

[42] G. Clarke. Situational crime prevention: Theory and practice. British Journal of Criminology, 20(1) (1980). $136-147$. https://doi.org/10.1093/oxfordjournals.bjc.a047153.

[43] B. Cornish and G. Clarke. Opportunities, precipitators, and criminal decisions: A reply to Wortley's critique of situational crime prevention. Crime Prevention Studies, 16 (2003) 41-96. http://127.0.0.1:9614/204.

[44] P. M. Cozens, G. Saville and D. Hillier. Crime prevention through environmental design (CPTED): a review and modern bibliography, Property Management, Vol. 23 Issue: 5, (2005) 328-356. https://doi.org/10.1108/02637470510631483.

[45] K. R. Wortley. Situational precipitators of crime. In: Wortley, R and Mazerolle, L, (eds.) Environmental criminology and crime analysis. Willan Pub (2008) 48-69.

[46] KSIA. Kenya Security Industry Association (2005) http://www.ksia.co.ke.

[47] PSIA. Private Security Industry Association (2018) http://www.psia.com. 